\title{
The occurrence of phenylpropanoids in the saps of six Piper species (Piperaceae) from Brazil
}

\section{La ocurrencia de fenilpropanoides en las savias de seis especies de Piper (Piperaceae) de Brasil}

\author{
Rafaela F. Paz ${ }^{1}$, Elsie F. Guimarães ${ }^{2} \&$ Clécio S. Ramos ${ }^{1 *}$ \\ ${ }^{1}$ Department of Chemistry, Rural Federal University of Pernambuco, Dom Manoel de Medeiros, s/n, Dois Irmãos, CP 52.171- \\ 030, Refie-PE, Brazil. \\ ${ }^{2}$ Rio de Janeiro Botanic Garden Research Institute, Jardim Botânico, 1008, CP 22.460-070, Rio de Janeiro-RJ, Brazil. \\ *clecio.ramos@ufrpe.br
}

\begin{abstract}
RESUMEN
Las especies de la familia Piperaceae son ampliamente investigadas debido a su importancia biológica, económica y ecológica. Sin embargo, los estudios químicos con las savias de la familia de las Piperaceae no han recibido tanta atención como la mayoría de otras especies de plantas. El presente estudio demostró la presencia de fenilpropanoides en la savia de seis especies de Piperaceae. Este estudio contribuye significativamente al conocimiento químico de la savia vegetal, hasta el momento poco explorado.
\end{abstract}

It is well known that phloem and xylem vessels transport a water-based solution with nutrient molecules over long distances in higher plants (Kehr \& Rep 2007). Sap phloem contains manly carbohydrates and other organic molecules, such as amino acids, proteins, hormones, and plant hormone, as well as inorganic ions. Xylem is involved in the transport of water and inorganic nutrients from the soil to the aerial parts of the plant (Krishnan et al. 2011). The occurrence of secondary metabolites is not expected in either phloem or xylem tissues. There are rare and isolated reports of the occurrence of secondary metabolites in some types of sap. In the phloem of Castanospermum austral A. Cunn. \& C. Fraser ex Hook. (Fabaceae), the indolizidine alkaloid castanospermine (Molyneux et al. 1990) has been found; in the xylem sap of maize Zea mays L. var. mays (Poaceae), the phenylpropanoids coumaric, caffeic and ferulic acids (Alvarez et al. 2008) were found. An analysis of sap from the Piper solmsianum C. DC. stems showed that it belongs to the Piperaceae family, indicating the presence of two secondary metabolites the (-)-grandisin and $E$-isoelemicin in the phloem of the plant (Ramos \& Kato 2012). Lichen phenolics have been found in the xylem sap of Quercus pyrenaica Willd. (Fagaceae) (Avalos et al. 1986).

The Piperaceae family and the Chlorantaceae family are considered as basal angiosperms, with approximately 3,000 species described to date (Jaramillo et al. 2004). The Piperaceae family is currently divided into five genera: Macropiper, Zippelia, Piper, Peperomia and Manekia. The
Piper genus is considered the most expressive of this family, with more than 1,000 species identified (Nascimento et al. 2012). The Piper species have been extensively studied and documented due to their medicinal and pesticide proprieties attributed to the presence of diverse secondary metabolites found in their tissues (Scott et al. 2007). Phytochemical studies with the Piper species have revealed a variety of secondary metabolite classes such as amides, phenylpropanoids, prenylated benzoic acids, flavonoids, alkaloids, terpenes, chromenes, lignans and neolignans. The piplartine, an amide first isolated from the Piper longum L., exhibits diverse pharmacological activities (Bezerra et al. 2013). Amides isolated from the Piper species, such as piperine, piperiline, pellitorine, pipercide and guineensine, manifest potent insecticidal activity against diverse insect orders (Kwute et al. 2013). The Piper species have been a model genus for ecological and evolutionary studies. Members of this species of great ecological importance and are considered important because of their association with frugivorous bats (Jaramillo \& Paul 2001). Given the economic, ecological, chemical and biological importance of the Piper species, and in order to contribute to knowledge of the chemical content of the sap in these plants, we have addressed the identification of secondary metabolites in the sap of six Piper species in this study.

The species selected were Piper aduncum L. (HST 18177), P. caldense C. DC. (HST 18180), P. arboreum Aubl. (HST 18179), P. tuberculatum Jacq. (HST 18178) and 
P. marginatum Jacq. (48210). These were collected from a fragment of the Atlantic Forest located on the campus of Federal Rural University of Pernambuco (UFRPE) in Recife, Pernambuco, Brazil. A voucher specimen of each plant was deposited in the Vasconcelos Sobrinho Herbarium of UFRPE. P. divaricatum G. Meyer (Kato 1063) was collected in the city of Itabuna, Bahia state, Brazil, and a voucher specimen deposited in the Botanical Institute Herbarium, São Paulo, Brazil. The plants were identified by Dr. Elsie F. Guimarães.

The saps of six Piper species were collected between 10:00 AM and 12:00 AM. The sap was obtained using a gentle vacuum to suck the vessel content from stem segments. Because a vacuum cannot pull air thought the pit fields at the ends of the vessels, successive segments were cut from the stem to release the vessel contents. All sap samples were frozen immediately after sampling and stored at $-80{ }^{\circ} \mathrm{C}$ until analyzed. The saps were extracted with ethyl acetate. The organic fraction was concentrated in a vacuum yielding the crude extracts. The saps were analyzed by GC$\operatorname{MS}\left(60-240^{\circ} \mathrm{C}\right.$ at $3{ }^{\circ} \mathrm{C}$ min rate) in a Varian $431-\mathrm{GC}$ coupled to a Varian 220-MS instrument using a fused-silica capillary column $(30 \mathrm{~m} \times 0.25 \mathrm{~mm}$ i.d. $\times 0.25 \mu \mathrm{m}$. $)$ coated with DB5. The injector and detector temperatures were 250 and 260 ${ }^{\circ} \mathrm{C}$, respectively. Hydrogen was used as the carrier gas at a flow rate of $1.5 \mathrm{~mL} / \mathrm{min}$; injection was in split mode (1:100) and the injection volume was $1.5 \mu \mathrm{L}$ of a solution containing ca. $2 \mathrm{mg} / \mathrm{mL}$ of each extract in methanol. MS spectra were obtained using electron impact at $70 \mathrm{eV}$ with a scan interval of $0.5 \mathrm{~s}$ and mass range from 40 to $550 \mathrm{~m} / \mathrm{z}$. Identification of the components was based on $\mathrm{GC}$ retention indices with reference to homologous series of $\mathrm{C}_{7}-\mathrm{C}_{30}$ n-alkanes calculated using the Van den Dool and Kratz (Van den Dool \& Kratz 1963) equation and by computer matching against the mass spectral library of the GC-MS data system as well as other published mass spectra (Adams 2007).

Sap dichloromethane fractions of the six Piper species: were analyzed by GC-MS (Fig. 1) and data interpretation indicated the presence of twenty-one secondary metabolites in the six saps analyzed. Phenylpropanoids were the major compounds detected in the six Piper species.

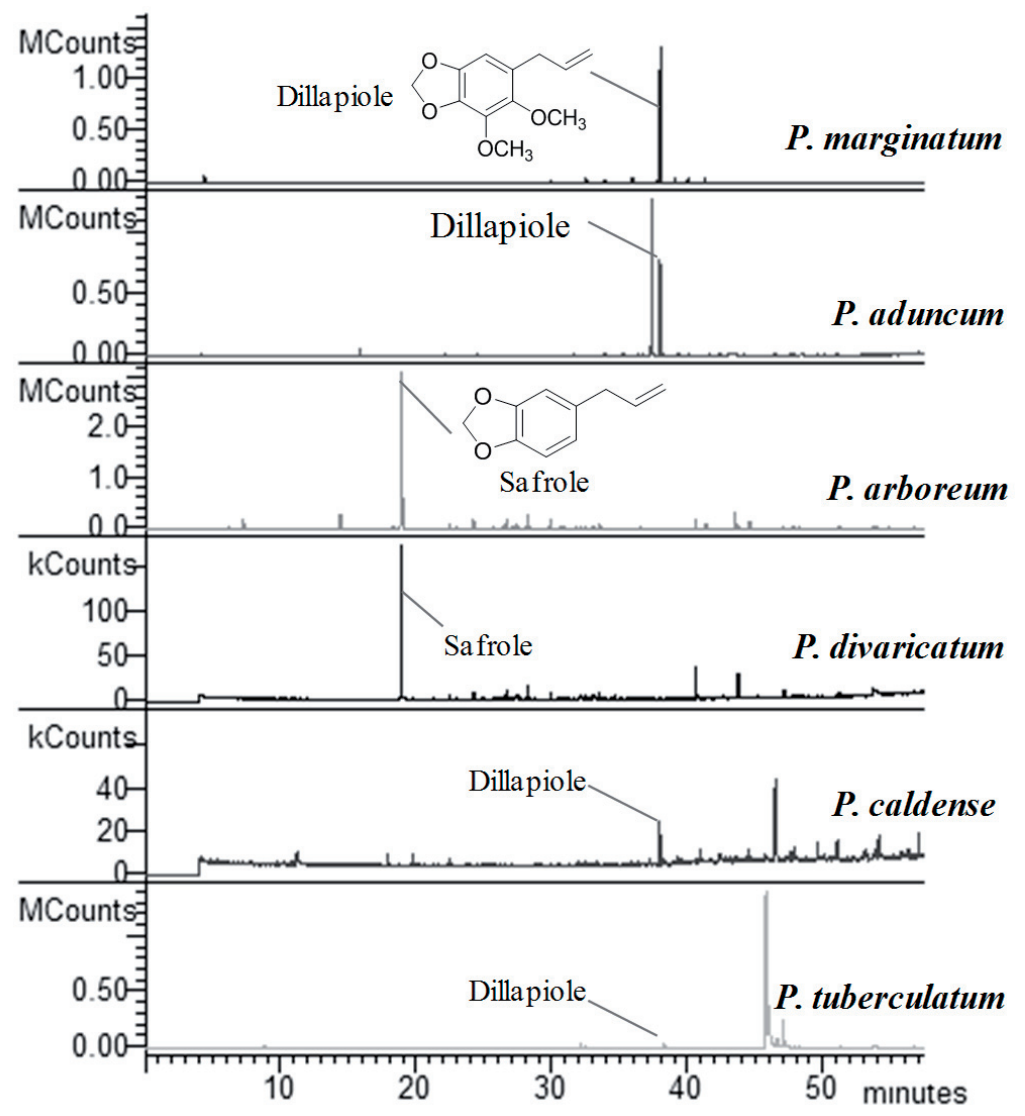

FIGURE 1. Sap chemical profiles from the Piper species obtained by GC-MS and the chemical structures of phenylpropanoids, safrole and dillapiole. / Perfiles químicos de la savia de las especies de Piper obtenidos por GC-MS y la estructura química de fenilpropanoides, safrol y dillapiole. 
Phenylpropanoid dillapiole was identified in the saps from $P$. marginatum, $P$. aduncum, $P$. caldense and $P$. tuberculatum with relative percentages of $76.9 \%, 34.7 \%, 8.5 \%$ and $1.3 \%$, respectively. Phenylpropanoid safrole was found in the saps of $P$. divaricatum (57.8\%) and $P$. arboreum (56.4\%). Other phenylpropanoids such as apiole, $E$-azarone, $Z$-azarone, as well as diverse terpenes, were also identified in the saps (Table 1). The largest number of secondary metabolites was identified in the $P$. marginatum sap, including four phenylpropanoids and five sesquiterpenes.

The discovery of phenylpropanoids as chemotypes in the saps of the Piper species was unexpected, and the function of most of these phenylpropanoids in the saps is not yet well understood. The phenylpropanoids dillapiole, $E$-azarone, $Z$-azarone, apiole and safrole found in the Piper saps have already been reported as potent natural insecticidal agents, and may be associated with the chemical defense of the plants against sap-sucking insects. Another possible explanation for the occurrence of phenylpropanoids the sap is that they are only translocated to diverse tissues of plant for the biosynthesis of more complex secondary metabolites, thus these phenylpropanoids are precursors of various metabolites such as lignans, lignins and flavonoids, usually found in the Piper species.

TABle 1. Chemical composition of compounds present in the sap content from Piper species. / Composición química de compuestos presentes en el contenido de savia de las especies de Piper.

\begin{tabular}{|c|c|c|c|c|c|c|c|c|}
\hline \multirow[b]{2}{*}{$\mathrm{N}^{\mathrm{o}}$} & \multirow[b]{2}{*}{ COMPOUNDS $^{\mathrm{a}}$} & \multirow[b]{2}{*}{$\mathrm{RI}^{\mathrm{b}}$} & \multicolumn{6}{|c|}{ RELATIVE AMOUNT (\%) } \\
\hline & & & PA & $\mathrm{PC}$ & $\mathrm{PD}$ & $\mathrm{PM}$ & PT & $\mathrm{PU}$ \\
\hline 1 & 3-Methyl-3-buten-1-ol & 723 & & 7.5 & & & & \\
\hline 2 & Isobornyl formate & 1235 & & 1.0 & & & & \\
\hline 3 & Safrole & 1285 & 56.4 & & 57.9 & & & \\
\hline 4 & $\alpha$-Copaene & 1374 & 1.3 & & & & & \\
\hline 5 & Caryophyllene & 1417 & 2.5 & & 3.1 & & & \\
\hline 6 & cis-Muurola-4(14),5-diene & 1465 & 1.1 & & 2.9 & & & \\
\hline 7 & Germacrene D & 1484 & & & 5.4 & & & \\
\hline 8 & Farenal & 1508 & & & & & & \\
\hline 9 & Apofarnesal & 1520 & & & & 0.3 & & \\
\hline 10 & Liguloxide & 1536 & & & & 0.7 & & \\
\hline 11 & Germacrene B & 1559 & & & & 0.4 & & \\
\hline 12 & Guaiol & 1600 & & & & 2.0 & & \\
\hline 13 & $Z$-Azarone & 1616 & & & & 0.4 & & 0.9 \\
\hline 14 & Isolongifolan-7- $\alpha$-ol & 1618 & & & & 0.3 & & \\
\hline 15 & Dillapiole & 1620 & & 8.5 & & 76.9 & 1.3 & 34.4 \\
\hline 16 & epi- $\alpha$-Cadinol & 1638 & & & & 0.5 & & \\
\hline 17 & $\alpha$-Muurolol & 1644 & 2.5 & & & & & 3.0 \\
\hline 18 & Cubenol & 1645 & 1.2 & & & & & \\
\hline 19 & 7-epi- $\alpha$-Eudesmol & 1662 & 3.4 & & & & & \\
\hline 20 & $E$-Azarone & 1675 & & & & 2.5 & & \\
\hline 21 & Apiole & 1676 & 1.0 & & & 1.9 & & \\
\hline
\end{tabular}

${ }^{a}$ Compounds are listed in order of their elution from an DB-5MS column. ${ }^{b}$ Retention indices as determined on non-polar DB-5MS column using the homologous series of n-alkanes. PA: P. arboreum; PC: P. caldense; PD: P. divaricatum; PM: P. marginatum; PT: P. tuberculatum; PU: P. aduncum. / aLos compuestos se enumeran en orden de su elución de una columna DB-5MS. bÍndices de retención determinados en columna DB-5MS no polar usando la serie homóloga de n-alcanos. PA: P. arboreum; PC: P. caldense; PD: P. divaricatum; PM: P. marginatum; PT: P. tuberculatum; PU: P. aduncum. 
In summary, we found secondary metabolites in the sap of the Piperaceae species in the form of dillapiole and safrole compounds, distinguished as insecticidal agents because of their allelochemical properties. This indicates that the sap contents may be involved in plant defense against natural enemies.

\section{ACKNOWLEDGMENTS}

The authors are indebted to the Centro de Apoio a Pesquisa (CENAPESQ), UFRPE, for the laboratory facilities.

\section{REFERENCE}

Adams, R.P. 2007. Identification of Essential Oil Components by Gas Chromatography/Mass Spectrometry. Ed. Allured Publishing, Carol Stream, IL, 804 p.

Alvarez, S., Marsh, E.L., Schroeder, S.G., Schachtman, D.P. 2008. Metabolomic and proteomic changes in the xylem sap of maize under drought. Plant Cell and Environment 31: 325-340.

Avalos, A., Legaz, M.E., Vicente, C. 1986. The occurrence of lichen phenolics in the xylem xap of Quercus pyrenaica, their translocation to leaves and biological significance. Biochemical Systematics and Ecology 4: 381-384.

Bezerra, D.P., Pessoa, C., De Moraes, M.O., Saker-Neto, N., Silveira, E.R., Costa-Lotufo, L.V. 2013. Overview of the therapeutic potential of piplartine (piperlongumine). European Journal of Pharmaceutical Sciences 48: 453-63.

Jaramillo, M.A., Manos, P.S., Zimmer, E.A. 2004. Phylogenetic relationships of the perianthless Piperales: reconstructing the evolution of floral development. International Journal of Plant Sciences 165: 403-416.

Jaramillo, M.A., Paul, S. 2001. Phylogeny and patterns of floral diversity in the genus Piper (Piperaceae). American Journal of Botany 88: 706-716.

KeHr, J., Rep, M. 2007. Protein extraction from xylem and phloem sap plant proteomics. Methods in Molecular Biology 355: 27-35.

Krishnan, H.B., Natarajan, S.S., Bennett, J.O., Sicher, R.C. 2011. Protein and metabolite composition of xylem sap from field-grown soybeans (Glycine max). Planta 233: 921-931.

Kwute, S. K., Egharevba, H.O. 2013. Piperine-type amides. Review of the chemical and biological characteristics. International Journal of Chemistry 5: 99-12.

Molyneux, R.J., Campbell, B.C., Dreyer, D.L. 1990. Honeydew analysis for detecting phloem transport of plant natural products: implications for host-plant resistance to sapsucking insects. Journal of Chemical Ecology 16: 1899-909.

Nascimento, J.C., Paula, V.F., David, J.M., David, J.P. 2012. Occurrence, biological activities and ${ }^{13} \mathrm{C}$ NMR data of amides from Piper (Piperaceae). Química Nova 35: 22882311.

Ramos, C.S., Kato, M.J. 2012. Secondary metabolites from the phloem of Piper solmsianum (Piperaceae) in the honeydew of Edessa meditabunda. Phytochemical Analysis 23: 604606.

Scott, I.M., Jensen, H.R., Philogene, B.J.R., Arnason, J.T. 2007. A review of Piper spp. (Piperaceae) phytochemistry, insecticidal activity and mode of action. Phytochemistry Reviews 7: 65-75.

VAN DEN Dool, H., KRATZ, P.H. 1963. A generalization of the retention index system including linear temperature programmed gas-liquid partition chromatography. Journal of Chromatography A 11: 463-471.

Recibido: 28.04 .2016

Aceptado: 20.03.2017 